\title{
EVALUATION OF SEWAGE SLUDGE APPLICATIONS ON CHEMICAL COMPOSITION OF Casuarina cunninghamiana WOOD

\author{
Abdel-Aal, M.A.M. ${ }^{1}$, A.S. Mohareb ${ }^{2}$ and N.D. Shetta ${ }^{2}$ \\ ${ }^{1}$ Forestry and Wood Tech. Dept., Horticulture Res. Inst., Agric. Res. \\ Center, \\ ${ }^{2}$ Forestry and Wood Tech. Dept., Fac. of Agric.,Alexandria Univ.
}

\begin{abstract}
The effect of sewage sludge treatments and tree heights on chemical composition of nine years old Casuarina cunninghamiana wood was evaluated at North West Coast of Egypt. Three treatments (control, dried sludge and sewage sludge) and three heights levels (stem base, breast height and $50 \%$ of total stem height) were investigated using different standard methods. The results generally indicated that, wood chemical constituents were varied widely among the treatments and heights levels. The extractives, cellulose, hemicellulose, lignin and ash contents were exhibited highly significant differences among the tested treatments. The sewage sludge treatment increased extractive and ash content, while the extractives, cellulose and lignin contents decreased with increasing of tree height levels. The determined cellulose contents at the different treatments (control, dried sludge and sewage sludge) were $41.14 \%, 40.28 \%$ and $44.30 \%$, while the hemicellulose content were $29.68 \%, 29.11 \%$ and $26.72 \%$ respectively. From the results, there is a clear influence for sewage sludge application on the chemical composition of Casuarina wood at different height levels. This is very important to chemical technologists and wood scientists working on pulp wood quality of hardwoods. Finally, the use of the sewage sludge as fertilizer for woody trees is a proper alternative for solving of the problems of disposal of sewage sludge. From a practical point of view, the sewage sludge application can be also increase cellulose content and reduce the lignin percentage in the treated tree. This trend can be contributed in achieve a high pulp yield from wood.
\end{abstract}

\section{INTRODUCTION}

The beneficial effects of using sludge on agriculture have been proven by numerous researchers. It has been shown that, sewage sludge application increased plant biomass and yield (Cogger et al., 2001; Brofas et al., 2000; Snyman et al., 1998; Kandeel and Kherallah, 1992; Abohassan et al., 1988). Two major environmental problems are the disposal of sewage sludge and the deterioration of soils. Also the sewage sludge application up to $300 \mathrm{t} / \mathrm{ha}$ produced a high biomass in apple trees and growth of apple seedlings (Solov and Khamyakov 1989). Another interesting finding was obtained on sewage sludge application by Awad et al. 1995, who found a significant increasing of apple seedlings growth.

Sewage sludge application may lead to the accumulation of a number of potentially harmful components such as heavy metals in soil and crops. The presence of heavy metals in the applied sludge can result in phytotoxic effects and accumulation of heavy metal in food supplies (Keller et al., 2002; Yingming and Corey, 1993). The application of sewage sludge to 
vegetable and fruit production has been limited by a lot of countries. Sewage sludge can be used for producing non-foodchain crops such as forest trees for fiber, fuel, construction, etc. Trees have diverse uses, both presently and in the immediate future. Sludge application to such non-foodchain crops may be particularly useful for sludges that are difficult to dispose of, (Bozkurt and Yarilgac, 2003; and Lambert et al., 1985). Murphey et al. (1973) found additional mass produced from Red oak as a result of irrigation by treated sewage effluent, and this weight is, for the most part, made up of the cells most desirable for pulp.

The chemical composition of wood profoundly affect the utilization of wood varying widely with wood species and within tree, because wood is not a uniform substance. Thus the trees with high cellulose content and low lignin content are usually preferred for pulp and paper making. Trees rich in extractive materials could have a higher potential for production of certain chemicals such as tannins, resins and rubber. Chemically, wood cell walls are composed of three groups of structural substances cellulose, hemicellulose, and lignin. Cellulose as the framework substance, contributes its high tensile strength to the complex of wood structure. The presence of hemicelluloses in the cell wall has a tremendous influence on certain physical properties of wood. The function of lignin is to provide rigidity and stiffness to cell walls (Rowell, 2005).

In addition to the three major chemical components (cellulose, hemicellulose and lignin), wood also contains quantities of extraneous components (extractives) which influence on the characteristics of wood, including sorption, shrinkage, adhesion, wettability, specific gravity, compressive and bending strength. (El-Osta et al. 1980; Badran and El-Osta, 1977 a and b; Hillis, 1972; Arganbright, 1971; Chen, 1970; Choong, 1969; Wangaard and Grandos, 1967 and Hancock and Swan, 1965). Ash is another secondary wood component and is considered an undesirable material in most industrial situations. The increase of wood utilization as a fuel may cause an ash disposal problem because it will accumulate in furnaces, this problem may be eliminated since ash is useful as a soil conditioner and fertilizer when supplemented with nitrogen (Karchesy 1979 and Tillman, 1978).

Wood chemical composition is an important technology property for wood industries field. Therefore, before suggesting proper utilization of tree woody biomass, it is essential to evaluate the basic technological properties of its wood. This study is superior scientific research to assay the influence of sewage sludge applications on the chemical composition of wood in Egypt. The aim of the present study is to evaluate sewage sludge applications on chemical composition of Casuarina woods.

\section{MATERIALS AND METHODS}

The present investigation was carried out at Amria Station for Water and Drainage (site N9) during 2007 to evaluate the sewage sludge applications on chemical composition of Casuarina cunninghamiana wood. Nine healthy trees of Casuarina cunninghamiana were selected from nine 
years old stand in North West Coast of Egypt at Amria Station for Water and Drainage (site N9), $35 \mathrm{~km}$ from Alexandria city. The area (10 feddans) was divided to three plots (about three feddans for each plot). The plots were treated as a following; 1 ) dried sludge (10 tons sludge/feddan per year), 2) sewage sludge $\left(2000 \mathrm{~m}^{3}\right.$ sewage sludge/feddan per year) as fertilizer applications and control. The previous treatments were applied on the stand trees from the beginning of the trees plantation (nine years ago).

Nine straight trees (three trees from each treatment) were selected to determine the percentages of chemical constituents of wood produced from the treated trees and control. Three sound discs (about $1.5 \mathrm{~cm}$ in thickness) were taken from each tree at three different height levels namely: stem base, breast height, and $50 \%$ of the total stem height. In order to prevent dryness, the discs were placed in plastic bags and transported to the laboratory and stored in freezing temperature for further processing.

\section{Extractives content determination}

Air dried wood meal 40-60 mesh was extracted in a soxhlet extractor apparatus for four hours with a mixture of two volume of benzene to one volume $95 \%$ ethanol, followed by four hours extraction with $95 \%$ ethanol, and finally extracted with hot-water for four hours. The percentage of extractives was calculated based on the oven-dry weight of wood samples based on ASTM standard D1105-56 (1989).

\section{Cellulose content determination}

Cellulose content was determined by the treatment of extractive-free wood meal with nitric acid and sodium hydroxide: one gram of extractive-free wood meal was treated with $20 \mathrm{ml}$ of a solution of nitric acid $3 \%$ in flask and was boiled for $30 \mathrm{~min}$. The solution was filtered in crucible G3. The residue was treated with $25 \mathrm{ml}$ of a solution of sodium hydroxide $3 \%$ and was boiled for $30 \mathrm{~min}$. The residue was filtered, washed with warm water to neutral filtrate, dried and weighed. The cellulose content was calculated as percentage of residues based on oven dry wood meal weight (Nikitin, 1960).

\section{Hemicelluloses content determination}

Hemicellulose content was determined by the treatment of extractive free wood meal (1-2g) with $50-100 \mathrm{ml}$ sulfuric acid $2 \%$ and boiled for $1 \mathrm{hr}$. under a reflex condenser and filtrated in crucible G2. After that, the residue was washed with $500 \mathrm{ml}$ of hot distilled water to free of acid, and contents were dried in an oven at $105 \pm 2{ }^{\circ} \mathrm{C}$, cooled in a dessicator and weighed (Rozmarin and Simionescu, 1973).

Lignin content was calculated by difference as follows: Lignin $\%=100-$ (cellulose $\%+$ hemicellulose $\%$ ). And ash content of wood was determined according to the NREL Chemical Analysis and Testing Task Laboratory Analytical Procedure \#005, (1994).

\section{Statistical analysis}

The analysis of variance was carried out according to factorial experiments in CRD and the least significant difference method at $95 \%$ level of probability (L.S.D.05) was used to test the differences among the means of extractives, cellulose, hemicellulose, lignin and ash content (Neter et al., 1990). 


\section{RESULTS AND DISCUSSION}

Effect of fertilization treatments and height levels on extractive content

Table (1) shows the analysis of variance for extractive, cellulose, hemicellulose, lignin and ash content of sewage sludge treatments and height of Casuarina trees. The results indicated that, the differences among treatments with sewage sludge, height and interaction were highly significant in extractive content. The treatment with dried sludge gave the highest average values of extractive content $(12.56 \%)$ followed by sewage sludge $(11.91 \%)$ and the least average value was control (10.21\%) (Table 2). Overall, the fertilization with sewage sludge or dried sludge increased the extractive in Casuarina trees. It clear from Table (3) that, stem base had the highest average values of extractive content (12.59\%) followed by breast height $(11.54 \%)$ and the least average value was of $50 \%$ of total stem height (10.53\%).

The interaction between sewage sludge treatments and height, indicates that, the stem base with dried sludge treatment had the highest average values of extractive content $(13.69 \%)$ and the least average value was of control at $50 \%$ of the total stem height (8.82\%) (Table 4 and Figure 1).

The decreased in extractive content caused by increasing in height was in agreement with those obtained by Abdel-Aal and Shetta (2007) they found that, there was decrease in extractives with increasing the tree height level in River red gum wood (Eucalyptus camaldulensis). While the increased in extractive contents caused by dried sludge or sewage sludge fertilization were in agreement with Kherallah (1982) who found that sewage irrigated Eucalypt plantation contained significantly higher extractive, alpha cellulose, and ash contents.

Table (1): Analysis of variance of extractive, cellulose, hemicellulose, lignin and ash contents of sewage sludge fertilization treatments and height levels of Casuarina cunninghamiana wood.

\begin{tabular}{|l|c|c|c|c|c|c|}
\hline S.O.V & D.F. & Extractives & Cellulose & Hemicellulose & Lignin & Ash \\
\hline Treatments(T) & 2 & $* *$ & $* *$ & $* *$ & $* *$ & $* *$ \\
Height(H) & 2 & $* *$ & $* *$ & $* *$ & $* *$ & $* *$ \\
$\mathbf{T}^{*} \mathbf{H}$ & 4 & $* *$ & NS & $* *$ & NS & $* *$ \\
Error & 45 & & & & & \\
\hline Total & 53 & & & & & \\
\hline
\end{tabular}

N.S not significant

Table (2) Effect of fertilization treatments with dry and sewage sludge on chemical composition of Casuarina cunninghamiana wood.

\begin{tabular}{|l|c|c|c|c|}
\hline \multirow{2}{*}{$\begin{array}{l}\text { Chemical } \\
\text { composition (\%) }\end{array}$} & Control & Dried sludge & Sewage sludge & L.S.D.0.05 \\
\cline { 2 - 5 } & 10.21 & 12.56 & 11.91 & 0.19 \\
\hline Extractive & 41.14 & 40.28 & 44.30 & 0.73 \\
\hline Cellulose & 29.68 & 29.11 & 26.72 & 0.29 \\
\hline Hemicellulose & 29.18 & 30.60 & 28.98 & 0.78 \\
\hline Lignin & 1.55 & 2.02 & 1.82 & 0.08 \\
\hline Ash & \multicolumn{3}{|c|}{} &
\end{tabular}


Table (3) Effect of tree height levels on chemical composition of Casuarina cunninghamiana wood.

\begin{tabular}{|l|c|c|c|c|}
\hline \multirow{2}{*}{$\begin{array}{l}\text { Chemical } \\
\text { composition (\%) }\end{array}$} & \multicolumn{3}{|c|}{ Height levels } & \multirow{2}{*}{} \\
\cline { 2 - 5 } & Stem base & $\mathbf{B H}^{\star}$ & $\mathbf{5 0 \%}$ & L.S.D.0.05 \\
\hline Extractive & 12.59 & 11.54 & 10.53 & 0.19 \\
\hline Cellulose & 42.72 & 41.98 & 41.01 & 0.73 \\
\hline Hemicellulose & 26.56 & 28.31 & 30.63 & 0.29 \\
\hline Lignin & 30.71 & 29.70 & 28.36 & 0.78 \\
\hline Ash & 1.58 & 1.80 & 2.01 & 0.08 \\
\hline * BH : breast height. & \multicolumn{4}{|l}{} \\
\hline
\end{tabular}

${ }^{\star *} 50 \%: 50 \%$ of total stem height.

Table (4) Average values of wood chemical composition of sewage sludge treatments and height levels of Casuarina cunninghamiana wood.

\begin{tabular}{|l|l|c|c|c|c|c|}
\hline Treatments & Height & $\begin{array}{c}\text { Extractive } \\
\text { content\% }\end{array}$ & $\begin{array}{c}\text { Cellulose } \\
\text { content\% }\end{array}$ & $\begin{array}{c}\text { Hemicellulose } \\
\text { content\% }\end{array}$ & $\begin{array}{c}\text { Lignin } \\
\text { content\% }\end{array}$ & $\begin{array}{c}\text { Ash } \\
\text { content } \%\end{array}$ \\
\hline Control & Base & 11.39 & 41.90 & 27.70 & 30.39 & 1.40 \\
& $\mathrm{BH}$ & 10.40 & 41.18 & 29.67 & 29.14 & 1.58 \\
& $\mathbf{5 0 \%}$ & 8.82 & 40.34 & 31.64 & 28.01 & 1.66 \\
\hline Dried & $\mathrm{Base}$ & 13.69 & 41.39 & 26.72 & 31.89 & 1.67 \\
sludge & $\mathrm{BH}$ & 12.59 & 40.32 & 29.00 & 30.67 & 2.11 \\
& $\mathbf{5 0 \%}$ & 11.38 & 39.12 & 31.62 & 29.24 & 2.27 \\
\hline Sewage & $\mathrm{Base}$ & 12.69 & 44.89 & 25.27 & 29.83 & 1.64 \\
sludge & $\mathrm{BH}$ & 11.61 & 44.44 & 26.27 & 29.28 & 1.71 \\
& $\mathbf{5 0 \%}$ & 11.40 & 43.56 & 28.62 & 27.80 & 2.10 \\
\hline LSD 0.05 & & 0.33 & 1.26 & 0.52 & 1.35 & 0.14 \\
\hline
\end{tabular}

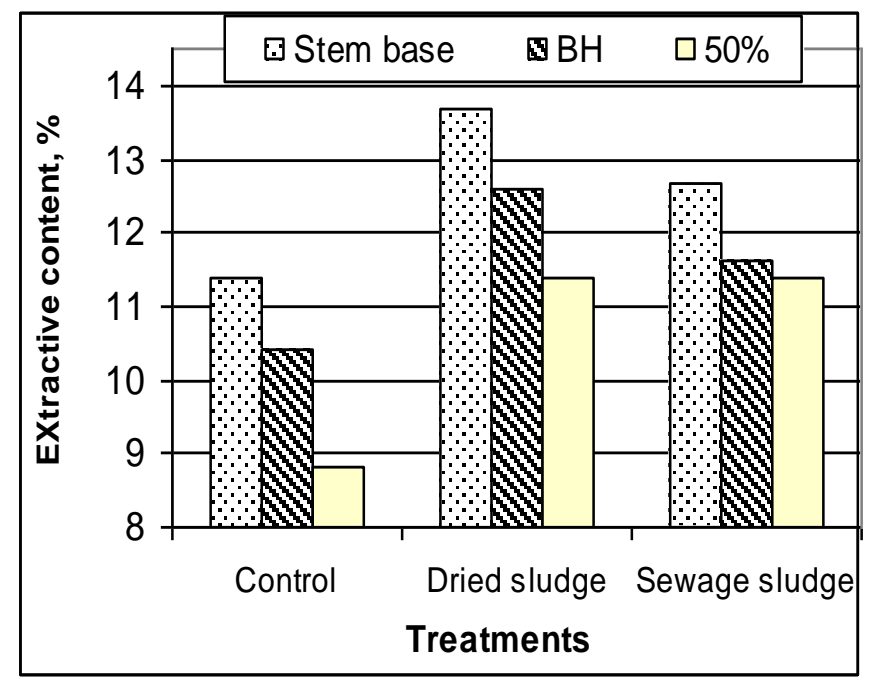

Figure (1): Effect of treatments with sewage sludge and height levels on extractive content of Casuarina cunninghamiana wood. 


\section{Effect of fertilization treatments and height levels on cellulose content}

The analysis of variance for cellulose content of sewage sludge treatments and height levels of Casuarina trees in Table (1) reported that, the differences among treatments with sewage sludge and heights were highly significant, while the interaction in cellulose content was not significant. The average values of cellulose content at sewage sludge treatment gave the highest value followed by the control treatment, while the lowest average was found with the dried sludge treatment. The averages were $44.30 \%, 41.14 \%$ and $40.28 \%$ respectively Table (2). The stem base had the highest average values of cellulose content $(42.72 \%)$ then at breast height $(41.98 \%)$ and the least average value was at $50 \%$ of the total stem height $(41.01 \%)$ (Table 3 and Figure 2).

The results obtained from fertilization with dried sludge were in agreement with (Harvey and Tsuneo 1974), who found that accelerated growth by fertilization caused a small decrease of $0.9 \%$ for cellulose content during the 6 years compared to uniform-growth trees. While the increase in cellulose content at sewage sludge treatment may be due to increase in latewood compared to earlywood or thicker fiber walls specially in S2 layer. These results were in agreement with Kherallah (1982) who found that the sewage irrigated Eucalypt plantation contain a significant increase in alpha cellulose content $54 \%$ vs. $47 \%$ for control.

Also, the decreased in cellulose content with height increase was in agreement with those obtained by Abdel-Aal and Shetta, 2007; Uprichard, 1971 and Senoo, 1970, who found that cellulose content decreased with increasing tress height.

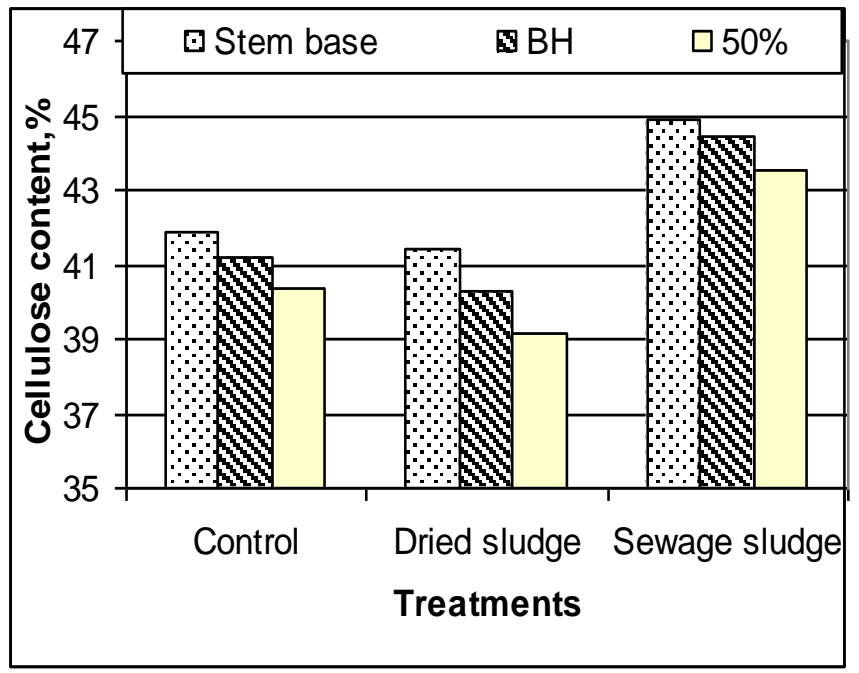

Figure (2): Effect of treatments with sewage sludge and height levels on cellulose content of Casuarina cunninghamiana wood. 


\section{Effect of fertilization treatments and height levels on hemicellulose content}

The analysis of variance for hemicellulose of sewage sludge treatments and heights of Casuarina trees in Table (1) indicates that, the differences among treatments with sewage sludge, height levels and the interaction were highly significant in hemicellulose content. Table (2) indicates that, the control gave the highest average values of hemicellulose content $(29.68 \%)$ followed by dried sludge $(29.11 \%)$, while the least average value was of sewage sludge $(26.72 \%)$. Overall, the fertilization by sewage sludge or dried sludge decreased hemicellulose content. These results were in agreement with Kherallah (1982) who found a highly significant decrease of hemicellulose in sewage irrigated Eucalyptus camaldulensis (28\% vs. $31 \%$ for control). The highest average value of hemicellulose was found at $50 \%$ of stem height $(30.63 \%)$, then at breast height $(28.31 \%)$. The lowest average value was found at the stem base $(26.56 \%)$. This result means, the hemicellulose content increased with height in the tree trunk (Table 3).

The interaction between fertilization treatments and height, (Table 4) indicates that, the control at $50 \%$ of stem height and dried sludge at $50 \%$ of stem height had the highest average values of hemicellulose content $(31.64 \%)$ and (31.62) respectively, while a lower average value was obtained from sewage sludge at the same level of height $(28.62 \%)$.In addition the least amount of hemicellulose content was detected with sewage sludge treatment at the stem base $(25.27 \%)$.

The increase in hemicellulose content with increasing height levels was in agreement with those results obtained by Abdel-Aal and Shetta (2007) who found increase in hemicellulose content with increasing the tree height level. The same trend was found by Harwood (1971) who found that in Pinus radiata the xylose, galactose and arabinose contents increased slightly with increasing height in the tree trunk.

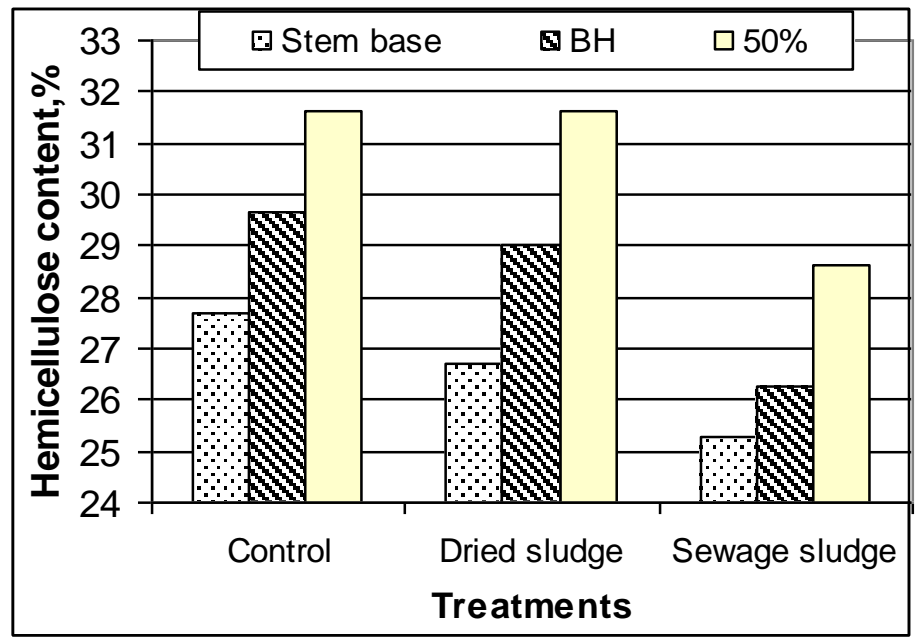

Figure (3): Effect of treatments with sewage sludge and height levels on hemicellulose content of Casuarina cunninghamiana wood. 


\section{Effect of fertilization treatments and height levels on lignin content}

Table (1) shows the analysis of variance for lignin content of sewage sludge treatments and height levels of Casuarina trees. The results reported that, the differences among treatments with sewage sludge as well as height levels effect were highly significant, while the interaction effect on lignin content was not significant. Table (2) indicates that, the treatment with dried sludge gave higher average values of lignin content $(30.60 \%)$ compared to control treatment $(29.18 \%)$ and sewage sludge $(28.98 \%)$. The stem base had the highest average values of lignin content followed by breast height, while the lowest average value was at $50 \%$ of the total stem height. The averages were $30.71 \%, 29.70 \%$ and $28.36 \%$ respectively (Table 3 and figure 4).

The increased in lignin content by fertilization with dried sludge was in agreement with Harvey and Tsuneo (1974) who found that, accelerated growth by fertilization increased lignin content compared to control trees.

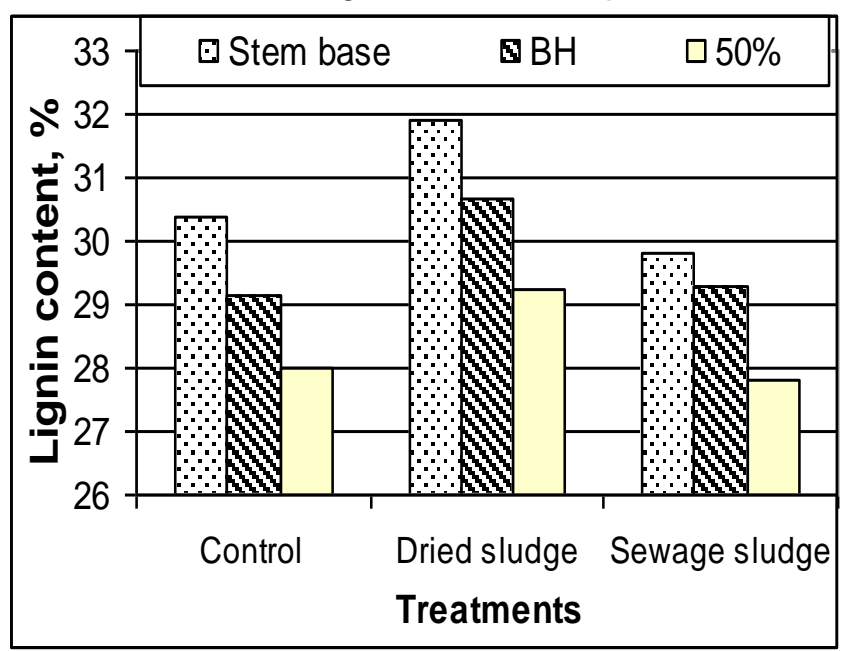

Figure (4): Effect of treatments with sewage sludge and height levels on lignin content of Casuarina cunninghamiana wood.

\section{Effect of fertilization treatments and height levels on ash content}

Table (1) illustrates the highly significant differences in ash content among treatments with sewage sludge, heights and the interaction. The dried sludge had the highest average values of ash content $(2.02 \%)$, then sewage sludge (1.82\%), but the least average value was of the control (1.55\%) (Table 2). Generally, the fertilization with sewage sludge or dried sludge increased ash content of wood compared with control in Casuarina trees. Ash content of wood at $50 \%$ of stem height had the highest average value than those of the breast height and the stem base. The average values were $2.01 \%, 1.80 \%$ and $1.58 \%$ respectively (Table 3 ).

The interaction between fertilization treatments and tree height levels indicated that, the dried sludge at $50 \%$ of total stem height had the highest average of ash content, while the lowest average value was found in the 
control treatment at stem base level. The averages values were $2.27 \%$ and $1.40 \%$ respectively (Table 4 and Figure 5 ).

The increase in ash content attributed to height levels was in agreement with the results of Abdel-Aal and Shetta (2007). They found that, there was an increase in ash content with increasing the tree height level.

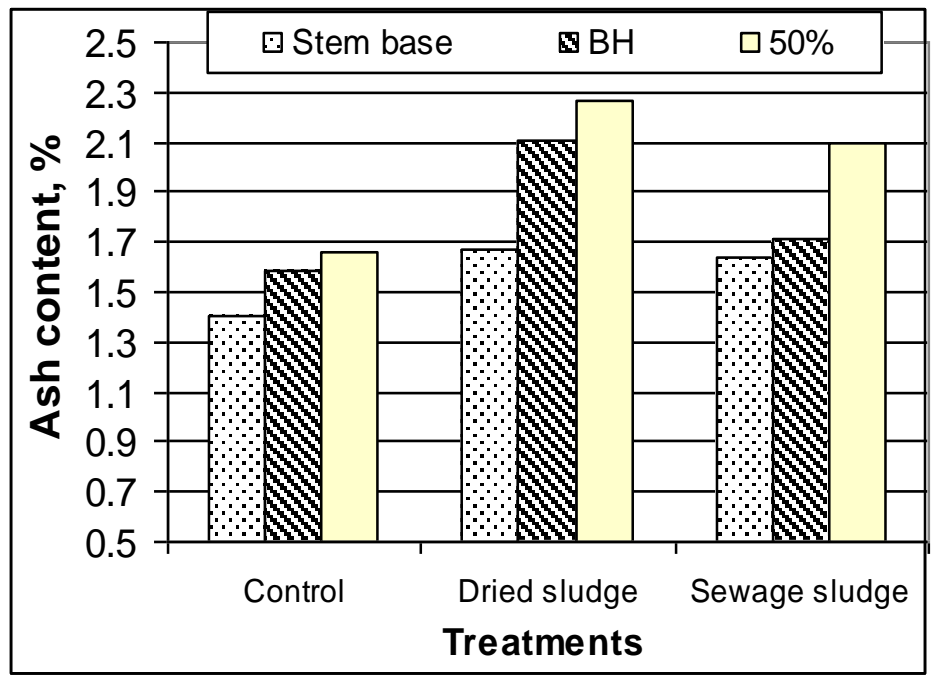

Figure (5): Effect of fertilization treatments with sewage sludge and height levels on ash content of Casuarina cunninghamiana wood.

\section{Conclusions}

Based on the results obtained from this study, it can be concluded that, sewage sludge fertilization treatments and height levels influenced on the chemical composition of Casuarina woods. Moreover, the comparison among sewage sludge treatments showed that, the dependent variables varied significantly. The sewage sludge fertilization treatments exhibited significantly higher values for extractives and ash content than the control. In comparison among stem heights, the highest averages of extractives, cellulose and lignin content were found at stem base with averages $12.59 \%$, $42.72 \%$ and $30.70 \%$ respectively, while at $50 \%$ of the total stem height found the highest of values hemicellulose and ash contents. The averages were $30.63 \%$ and $2.01 \%$ respectively.

The results of the present study showed that, clear influence of sewage sludge applications on the chemical composition of Casuarina wood at different tree heights. This is very important to chemical technologists and wood scientists working on pulp wood quality of hardwood trees. Finally, the use of sewage sludge applications as fertilizer seems to increase cellulose content and slightly reduce lignin content, this trend can be contributed in achieve a high pulp yield from wood. 


\section{Acknowledgement}

We would like to express our sincere appreciation to Mr. Hussein Mohamed Hassan the director of the Amria Station for Water and Drainage (site N9) to carry out the work in his station (N9). Special thanks to Mr. Nageb EL baher Vice director and responsible of the trees plantation in Amria Station for Water and Drainage for his kind assistance and providing the necessary information needed for the work.

\section{REFERENCES}

Abdel-Aal, M.A.M and N.D. Shetta (2007). Extractives, cellulose, hemicellulose and ash content variation in Eucalyptus camaldulensis trees grown in Egypt. Alex. J. Agric. Res. 52(2), 57-61.

Abohassan, A.A.; I.E. Kherallah and S.A. Kandeel (1988). Effect of sewage effluent irrigation regimes on wood quality of Prosopis juliflora grown in Riyadh regon. Arab. Gulf. J. Scient. Res. Agric. Biol. Sci. B6(1): 45-53.

Adam, M.T.; L.G. Barbara and J.M. Jeffrey (2006). Western redcedar extractives: Is there a role for the silviculturist? Forest products journal 56(3), 58-63.

American Society for Testing and Materials (1989). Standard test methods for preparation of extractive-free wood. ASTM D 1105-56. Philadelphia, Pa. U.S.A.

Arganbright, D.G. (1971). Influence of extractives on bending strength of redwood. Wood and Fiber 2(1), 367-372.

Awad, F.; L. Kahl; R. Kluge and I. Abadia (1995). Environmental aspects of sewage sludge and evaluation of super absorbent hydrogel under Egyptian conditions. In: Iron Nutrition in Soil and Plants. Proceedings of the Seventh International Symposium, Zaragoza, pp. 53-62.

Badran, O.A.; and M.L.M. EL-Osta (1977 a). Intra-increment specific gravity and total extractive of Casuarina glauca. Alex. J. Agric. Res. 25(3), 535-540.

Badran, O.A.; and M.L.M. EL-Osta (1977 b). Influence of specific gravity and extractive content on maximum crushing strength of wood. Alex. J. Agric. Res. 25(3), 541-548.

Bozkurt, M.A.; and T. Yarilgac (2003). The effects of sewage sludge applications on the yield, growth, nutrition and heavy metal accumulation in apple trees growing in dry conditions. Turk J. Agric. For. 27(3), 285-292.

Brofas, G.; P. Michopoulas and D. Alifragis (2000). Sewage sludge as an amendment for calcareous bauxite mine spoils reclamation. J. Environ. Qual. 29: 811-816.

Chen, C.M. (1970). Effect of extractives removal on adhesion and wettability of some tropical woods. For. Prod. J. 20 (1), 36-41.

Choong, E.T. (1969). The effect of extractives on shrinkage and other hygroscopic properties of ten southern pine woods. Wood and Fiber 1(2), 124-132. 
Cogger, C.G.; A.I. Bary; S.C. Fransen and D.M. Sullivan (2001). Seven years of biosolids versus inorganic nitrogen applications to tall fescue. J Environ. Qual. 30: 2188-2194.

El-Osta, M.L.M.; O.A. Badran and E.M.A. Ajoung (1980). Crushing strength of three Sudanese tropical hardwoods in relation to specific gravity, extractive and lignin content. Wood Sci. 13 (4), 225-232.

Hancock, W.V. and E.P. Swan (1965). Petroleum ether soluble extractives of British Columbia coastal and interior type Douglas fir. Phytochemistry 4(6), 791-798.

Harvey, D.E. and A. Tsuneo (1974). Douglas-fir wood quality studies part II: Effect of age and stimulated growth on fibril angle and chemical constituents. Wood Science and Technology, 8(4), 255-265.

Harwood, V.D. (1971). Variation in carbohydrate analyses in relation to wood age in Pinus radiata. Holzforschung, 25(3), 73-77.

Hillis, W.E. (1972). Properties of eucalypt woods of importance to the pulp and paper industry. Appita 26(2), 113-122.

Kandeel, S.A. and I.E. Kherallah (1992). Utilization of city sewage in the irrigation of protection forestry plantations in Egypt. IUFRO All-Division 5 conference "FP", Nancy-France (23-28, 1992).

Karchesy, J. and P. Koch (1979). Energy production from hardwoods growing on southern pine sites. U.S. Dept. of Agr., For. Serv. GTRSO-24. So For. Expt. Sta.

Kherallah, I.E.A. (1982). Chemical constituents and pulping characteristics of normal and sewage irrigated Eucalyptus camaldulensis Dehn grown in Egypt. Ph.D. thesis, Faculty of Agric., Alex. Univ.200pp.

Lambert, D.H.; T.C. Weidensaul; D.C. Borger and L.H. Rhodes (1985). Use of sewage sludge for forest-tree seedling production. United States Environmental protection Agency, 81-85.

Murphey, W.K.; W.J. Young and B.E. Cutter (1973). Effect of sewage effluent irrigation on various physical and anatomical characteristics of northern red oak. Wood Sci., 6(1): 65-71.

Keller, C.; S.P. McGrath and S.J. Dunham (2002). Trace metal leaching through a soil grassland system after sewage sludge application. J. Environ. Qual. 31: 1550-1560.

Neter, J; W. Wasserman and M. Kutner. (1990). Applied Linear Statistical Models. Third Edition, Irwin Boston , MA 02116, $1181 \mathrm{pp}$.

Nikitin, V.M. (1960). "Himia drevesini i telliulozi", Goslesbumiz_dat, M_L. Pg.233. Chimia Lemnului SI A Celuloze I Vol I si II,1973.

NREL CAT Task Laboratory Analytical Procedure \#005 (1994)“Standard Method for ash in Biomass".

Rowell, R. M. (2005). Handbook of wood chemistry and wood composites. Taylor and Francis group, Boca Raton, London, New York, Singapore.

Rozmarin, G., and C. Simionescu. (1973). Determining hemicellulose content. Wood Chemistry and Cellulose (Romanian) 2: 392.

Senoo, T. (1970). Studies on the cellulose productivity of Akamatsu (Pinus densiflora S.\&Z.) stands, III: On the variation of bulk density and cellulose content in the stems of old-matured trees, Bull. Kyoto prefect. Univ. For., no. 15, pp. 65-81 
Snyman, H.G.; J.M. de Jong and A.S. Aveling (1998). The stabilization of sewage sludge applied to agricultural land and the effects on maize seedlings. Wat. Sci. Tech. 38: 87-95.

Solov, I.S. and D.M. Khamyakov, (1989). Ecological aspects of using sewage sludge as fertilizer in apple orchards. Soviet Agricultural Sciences, 6: 30-33.

Tillman, D.A. (1978). Wood as an energy resource. Acad. Press Inc., N.Y.252 pp.

Uprichard, J.M. (1971). Cellulose and lignin content in Pinus radiate D. Don: Withen tree variation in chemical composition, Density and Tracheid length. Holzforschung, 25(4), 97-105.

Wangaard, F.F. and Grandos, L.A. (1967). The effect of extractives on water vapor sorption by wood. Wood Sci. Technol. 1(4), 253-277.

Yingming, L. and R.B. Corey, (1993). Redistribution of sludge borne Cd, Cu and $\mathrm{Zn}$ in a cultivated plot. J. Environ. Qual. 22: 1-8.

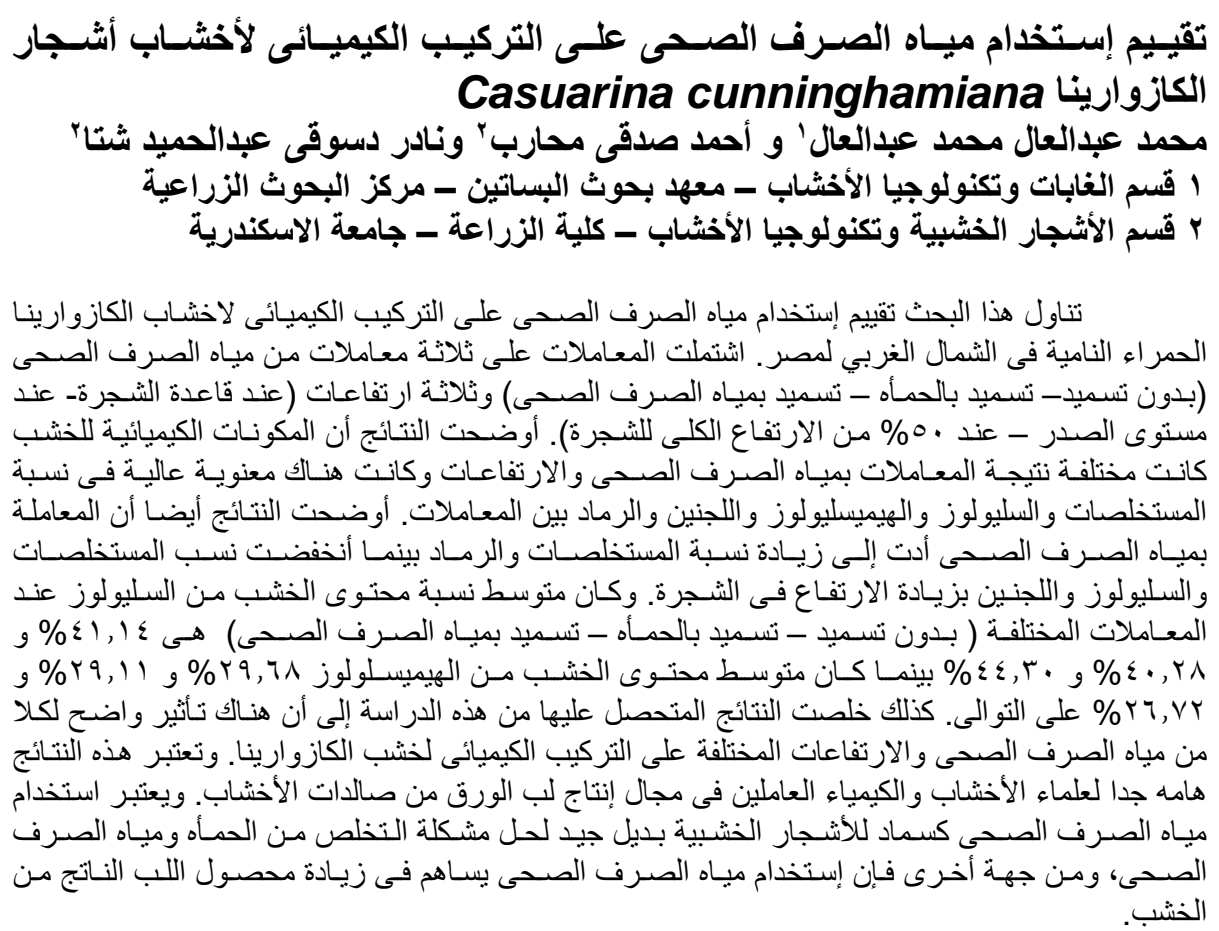

